\title{
Irrigation management methods for the production of bell pepper in agricultural substrates
}

Irai Manuela Santana Santos*, Pedro Pereira Santos Júnior, Rodrigo Rafael da Silva, Gertrudes Macário de Oliveira, Sérgio Oliveira Pinto de Queiroz

Universidade do Estado da Bahia - Departamento de Tecnologia e Ciências Sociais - Juazeiro (BA), Brazil.

ABSTRACT: This study's objective was to assess the response and effectiveness of irrigation management systems for the production of bell pepper with different agricultural substrates, under protected conditions. The current study was conducted in a greenhouse located in Juazeiro, BA, in the northwest of Brazil. The experiment design was completely randomized in a split-plot system, with two irrigation treatments as the main plots (the drainage lysimeter and the Piché evaporimeter) and two substrates in each sub-plot (coconut fiber and pinus bark), with 5 replications per treatment. Harvest was conducted from 86 to 151 days after transplanting, and the following characteristics were evaluated: total, marketable and unmarketable yields, production per plant, fresh mass of fruits, fruit number per plant, length and diameter of fruits, length/diameter ratio, water use efficiency, pulp thickness, fruit $\mathrm{pH}$, soluble solids, and titratable acidity.
No interaction effects between irrigation treatments and substrates were observed on the following variables: total yield, marketable yield, non-marketable yield, production per plant, mean mass, and diameter of marketable fruits. Irrigation treatments and substrates did not show a significant effect on bell pepper yield. Drainage lysimeter-based management and coconut fiber substrate had the best results in terms of the physical quality of fruits, whereas pinus bark-based substrate positively influenced all chemical variables and the Piché evaporimeter-based irrigation management showed a good performance raising fruit $\mathrm{pH}$ in relation to fruits cultivated in lysimeter with pinus bark. Additional research is required under different environmental conditions so that this crop fully expresses its yield potential.

Key words: Capsicum annuum, water management, evapotranspiration. 


\section{INTRODUCTION}

The consumer market of olericulture products is characterized by selectivity and high quality standards, which provides a high added value to the marketed product and justifies the adoption of new technologies that rationalize the use of inputs and natural resources. Bell pepper is one of the ten most consumed vegetables in Brazil (Agrianual 2012), with high economic importance in the national market, and is grown in several regions around the country. The largest cultivation areas are located in the Southeastern region, in the states of São Paulo and Minas Gerais, which together cultivate 5,000 ha, reaching a yield of approximately 120 thousand tons (Ribeiro and Cruz 2002). In recent years, its cultivation has been showing gains in productivity, especially when grown in protected environments (Lorentz et al. 2002). The Federal District stands out as the primary protected cultivation hub in the country (Pereira et al. 2011) and under these conditions, bell pepper yield might reach up to $150 \mathrm{t}^{\mathrm{h}} \mathrm{a}^{-1}$ (Lucio et al. 2011). Protected cultivation is an expanding consolidated technique that provides physical protection and mitigation of climatic adversities, being an alternative for the production of vegetables with maximized economic return and reduced seasonal effects on production (Pivetta et al. 2011). However, regional recommendations for crop management in such environments, mainly on water management, need to improve in order for these high-value crops to reach their full productive potential.

In addition, protected-grown vegetables in Brazil are still predominantly grown in soil, increasing the incidence of pests and phytopatogens that attack the root system, causing nutritional imbalances. Thus, substrate cultivation techniques emerge as an environmentally sustainable alternative to overcome such problems, They have gained prominence since they allow for a better use of nutrients, increasing yields, quality, and to facilitating farming practices. One of the main substrate components for the production of container crops is pinus bark (Fain et al. 2008), on the other hand, coconut fiber is also considered viable, since it is a highly-porous inert material, with easy production, low cost, and high availability.

As with most vegetables, bell pepper requires a regular water supply throughout its cycle, since it is sensitive to water deficiency and to excessive water in its growth substrate (Carvalho et al. 2011). Therefore, water replacement in the ideal amount and at the appropriate time is essential for adequate plant development and to obtain satisfactory yields.

Despite these requirements, vegetable irrigation and fertilization practices in Brazil have been performed empirically, and the lack of knowledge on water consumption under protected cultivation has provided unsatisfactory results (Furlani et al. 1998), compromising production and natural resources and resulting in increased production costs.

Overall, irrigation management might be conducted through several systems, which might be based on climatic parameters or on the growth substrate. One alternative to define the water requirement of crops in these environments consists of lysimeters, which directly define evapotranspiration, and another alternative is the use of evaporimeters, such as the Piché evaporimeter (Heldwein et al. 2001).

Therefore, the objective in this study was to assess the response and effectiveness of irrigation scheduling treatments on the production of bell pepper grown with different agricultural substrates, under protected conditions.

\section{MATERIAL AND METHODS}

The experiment was conducted in a protected environment covered with a black shading screen, with $50 \%$ of shading, and installed on wooden structures in the municipality of Juazeiro, Bahia (lat. 09० 24' 50" S; long. 40 30' 10" W; alt. $368 \mathrm{~m}$ ) in the period ranging from May to December 2014. According to Koppen's classification (Teixeira 2010), the climate is hot semiarid (BSwh), with mean annual rainfall of $540 \mathrm{~mm}$. Mean air temperature inside the protected environment was $26.3^{\circ} \mathrm{C}$ throughout the experiment according to data obtained from an automatic agro-meteorological station, with maximum of $31.4^{\circ} \mathrm{C}$ and minimum of $20.9^{\circ} \mathrm{C}$. During a large part of the crop cycle, temperature was above the optimal temperature range for bell pepper growth, which is 20 to $30^{\circ} \mathrm{C}$ (Blat and Costa 2007). Mean air relative humidity throughout the crop cycle was 54.5\%, corroborating the optimal range reported by Tivelli (1998).

A completely randomized experimental design was adopted with a split-plot system consisting of two irrigation treatments (drainage lysimeters and the Piché evaporimeter) as the main plots, and two organic substrates (pinus bark and coconut fiber) in the sub-plots, replicated five times. Experimental units were comprised of $5 \mathrm{~L}$ pots, with one plant grown per pot and two plants per plot. 
Substrates were submitted to physical-hydrological characterization in the laboratory. Volumetric densities of wet and dry samples were determined following the standards outlined by Normative Instruction number 17 of May 21, 2007 (Mapa 2007).

The substrate water retention curve was determined (Fig. 1) using the tension table method described by De Boodt and Verdonck (1972).

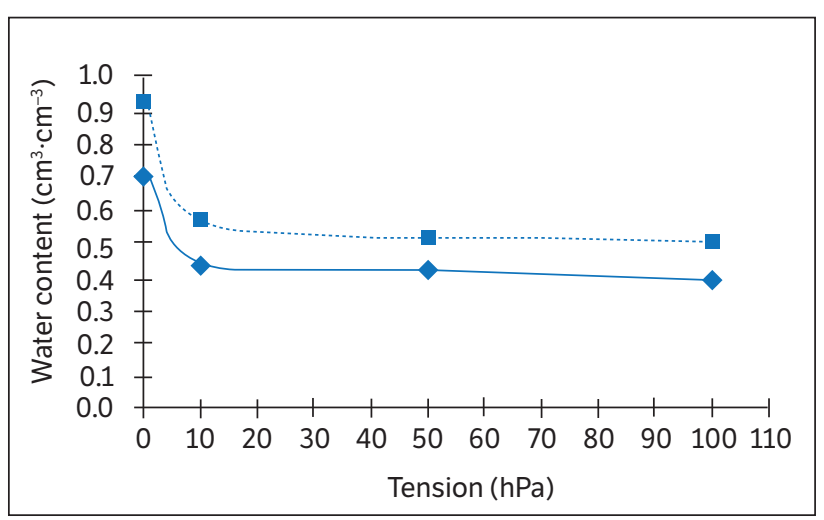

Figure 1. Typical water retention curves of substrates used under protected cultivation. Juazeiro, BA.

The chemical characterization of substrates was performed according to the water extraction method (1:1.5) adapted from Sonneveld and Elderen (1994). After extracting the solution, samples were sent to the Laboratory of Soil and Plant Analyses (LASP) for determination of $\mathrm{pH}$, electrical conductivity, macro and micronutrient contents at the beginning and end of the growth cycle, and organic matter content (Table 1).

Seedlings of the yellow hybrid bell pepper 'Lucia R' were produced on polystyrene trays, and subsequently transplanted to plastic containers. Transplanting was performed when seedlings had 4 to 5 definitive leaves, and one seedling was transplanted per pot. Plant spacing was $0.5 \mathrm{~m}$ between plants, and $1.0 \mathrm{~m}$ between rows. A staking system was assembled to support the plants using wires stretched between stakes, in each plant line and ribbon. Phytosanitary treatments were performed preemptively and curatively, using recommended products and doses as required.

In order to determine water depth and rate of application, drainage lysimeters were set on four pots for each one of the substrates and a Piché evaporimeter was installed inside the protected environment. The differential irrigation treatments started 18 days after transplanting.

Drainage lysimeters were installed in $5 \mathrm{~L}$ plastic pots. To prevent pot obstruction, a $2.5 \mathrm{~cm}$ layer of minced gravel was placed in the inner base of the lysimeters. The water requirements of the plants were determined on a daily basis, with the help of a graded test tube; a known amount of water was applied to the substrates and the water drained was measured. Based on the difference between the water volume supplied and the volume drained, water consumption was calculated in milliliters. Crop evapotranspiration was determined by converting consumption values (L) to evapotranspiration $(\mathrm{mm})$, and subsequently dividing them by pot area.

A Piché evaporimeter was installed inside the greenhouse, outside the meteorological shelter, exposed to solar radiation (Heldwein et al. 2001), and hung by a wire, so that the evaporating surface was situated $1.5 \mathrm{~m}$ above the ground. Water evaporation inside the protected environment was calculated by the difference in water level inside the millimetergraded tube between subsequent days.

Water was applied using a drip irrigation system, with drippers $0.5 \mathrm{~m}$ apart, under a nominal flow of $2.0 \mathrm{~L} \cdot \mathrm{h}^{-1}$ and nominal pressure of $1.0 \mathrm{kgf} \cdot \mathrm{cm}^{-2}$. One emitter was used per pot, and the volume of water was split in two daily applications.

The plants were fertilized with the nutrient solution recommended by Goto and Rossi (1997), and as cited by Trani and Carrijo (2004) for bell pepper culture. Nutrients were applied via fertigation, and the nutrient solution

Table 1. Chemical element analyses of the substrate samples, determined with a 1:1.5 extract (Adapted from Sonneveld and Elderen 1994).

\begin{tabular}{|c|c|c|c|c|c|c|c|c|c|c|c|c|c|c|c|}
\hline \multirow{2}{*}{ Substrate } & MO & $\mathbf{N}$ & $\mathbf{P}$ & $\mathbf{K}$ & $\mathrm{Ca}$ & Mg & C & B & $\mathrm{Cu}$ & $\mathrm{Fe}$ & Mn & $\mathbf{Z n}$ & $\mathbf{N a}$ & & \\
\hline & \multicolumn{7}{|c|}{$\left(g \cdot L^{-1}\right)$} & \multicolumn{6}{|c|}{$\left(\mathbf{m g} \cdot \mathrm{L}^{-1}\right)$} & $\left(d S \cdot m^{-1}\right)$ & Pri \\
\hline \multicolumn{16}{|c|}{ Beginning of the cycle } \\
\hline Pinus bark & 370 & 6.1 & 0.88 & 0.09 & 0.1 & 0.03 & 214 & 22 & 0.02 & 0.13 & 0.28 & 0.08 & 7.1 & 0.01 & 5.0 \\
\hline Coconut fiber & 800 & 7.3 & 1.19 & 0.8 & 0.01 & 0.01 & 464 & 33 & 0.01 & 0.01 & 0.01 & 0.07 & 14.1 & 0.15 & 6.2 \\
\hline \multicolumn{16}{|c|}{ End of the cycle } \\
\hline Pinus bark & 290 & 5.2 & 1.86 & 0.13 & 0.06 & 0.03 & 207 & 5 & 0.02 & 0.02 & 0.34 & 0.88 & 18 & 1.82 & 6.4 \\
\hline Coconut fiber & 780 & 7.5 & 5.39 & 0.13 & 0.14 & 0.05 & 452 & 38 & 0.01 & 0.01 & 0.01 & 0.09 & 8.3 & 1.09 & 6.4 \\
\hline
\end{tabular}


volume applied was similar to the irrigation rates applied in each treatment.

Harvest started 86 days after transplanting, when approximately $70 \%$ of the fruit skin was yellow colored, and extended to 151 days after transplanting (DAT), totaling three harvests during the crop cycle. The fruits were taken to the laboratory, where the following physical characteristics were analyzed: mean fruit length and diameter $(\mathrm{mm})$; length/diameter ratio and mean thickness of the pulp $(\mathrm{mm})$; fruit number per plant; total production per plant (g.plant $\left.{ }^{-1}\right)$; mean wet mass of fruits (g); total, marketable, and nonmarketable yield (expressed in $t \cdot h \mathrm{a}^{-1}$ ), The following chemical characteristics were also analyzed: soluble solid content ( $\left.{ }^{\circ} \mathrm{Brix}\right) ; \mathrm{pH}$; and titratable acidity, according to the method indicated by the Instituto Adolfo Lutz (2004). The fruits were classified by their size, according to the standards prescribed by CEAGESP (2014), as follows: marketable (length $>60 \mathrm{~mm}$ and diameter $>40 \mathrm{~mm}$ ) and non-marketable (length $<60 \mathrm{~mm}$ and diameter $<40 \mathrm{~mm}$, or presence of cosmetic defects).

The data was submitted to variance analysis and to Tukey's test $(\mathrm{p}>0.05)$ for multiple comparison of the means, using Assistant software version 7.7 beta (Silva and Azevedo 2002).

\section{RESULTS AND DISCUSSION}

Regarding volumetric density of wet samples, the pinus bark-based substrate had the highest values (Table 2). Sorace et al. (2009), studying alternative substrates for tree ferns in the cultivation of the hybrids Cattleya intermedia X Hadrolaelia purpurata, found density values of $0.46 \mathrm{~g} \cdot \mathrm{cm}^{-3}$ for coconut fiber substrate and $0.45 \mathrm{~g} \cdot \mathrm{cm}^{-3}$ for pinus bark. In container cultivation, known volumetric density value might work as a parameter for irrigation management (Fermino 2012). Marketable substrates have different grain sizes, thus affecting the macro and microporosity ratio, which in turn effects the availability of water and air in the substrates (Zorzetto et al. 2014). Coconut fiber substrate had lower wet and dry densities, resulting in higher porosity.

Table 2. Wet (WD) and dry (Dd) density of coconut-based and pinus bark-based substrates. Juazeiro, BA, 2014.

\begin{tabular}{ccc} 
Substrate & \multicolumn{2}{c|}{ Density $\left(\mathbf{g} \cdot \mathbf{c m}^{-3}\right)$} \\
\cline { 2 - 3 } & WD & Dd \\
\hline Coconut Fiber & 0.434 & 0.090 \\
\hline Pinus Bark & 0.526 & 0.296 \\
\hline
\end{tabular}

Based on the water retention curves (Fig. 1), a higher water retention was observed in the coconut fiber substrate, which allows for the water to be available to plants for a longer period. According to Ansorena Miner (1994), retained water is higher in substrates with small particles (up to $1.0 \mathrm{~mm}$ ), which increases the number of micropores that are responsible for water retention; this characteristic is a market trend.

In plants grown with pinus bark, lysimeter-based irrigation resulted in greater water application rates than with the Piché evaporimeter, with an accumulated value of 55.7 L-plant ${ }^{-1}$, accounting for a $1773.5 \mathrm{~mm}$ rate; whereas, with the evaporimeter, the total value was $44.3 \mathrm{~L} \cdot$ plant $^{-1}(1412.4 \mathrm{~mm})$. For the coconut fiber substrate, water consumption with the lysimeter was initially lower than the evaporimeter up to 75 DAT, however exceeding it by the end of the experiment. According to Doorenbos and Kassam (2000), the water requirements for bell pepper are approximately 600 to $900 \mathrm{~mm}$, and it might reach up to $1250 \mathrm{~mm}$ for longer growth periods, which might vary according to climate, variety used, and number of harvests. Lima et al. (2006), assessing the performance of 'Yolo Wonder' bell pepper in a greenhouse using both soil and a growth substrate, observed a total water consumption of $1232.8 \mathrm{~mm}$ for a 115 day cycle, in Recife, PE (northeast of Brazil). Thus, the high water application rate observed in the current experiment was related to the longer growth cycle, as well as to the local climate conditions. Moreover, the physical conditions of substrates and soils are different, affecting the water retention process, and consequently, the amount applied.

The results of fruit yield are shown in Table 3. The analysis of variance showed no significant interaction between irrigation and substrate treatments for these variables. The main factors, separately, showed that most variables were not significantly influenced by the type of irrigation and substrate treatments, except for mean mass of fruits and fruit number per plant.

The total cumulative mean yield for the three harvests was $14.59 \mathrm{t}^{\mathrm{h}} \mathrm{ha}^{-1}$ for the lysimeter-based system and $13.76 \mathrm{t} \cdot \mathrm{ha}^{-1}$ for pinus bark cultivation. Albuquerque et al. (2011), assessing the effects of different levels of irrigation and potassium doses in soil-grown bell pepper culture, found a mean yield of $18.58 \mathrm{t}^{\mathrm{th}} \mathrm{h}^{-1}$ over five harvests. The lower yields observed in this experiment might be attributed to the genetic material used, to environmental conditions with high temperatures, to irrigation frequency, which might have been affected by 
substrates with varying physical characteristics, or to other undetermined factors

For marketable yields, the mean values obtained with lysimeter and evaporimeter-based management accounted for 61.5 and $53.0 \%$ of total yields, respectively (Table 3). Apical-blossom end rot incidence resulted in the production of non-marketable fruits. According to Fontes (2003), the occurrence of apical-blossom end rot is determined by several factors, which include interactions between irradiation, temperature, water availability, physical characteristics of the soil, salinity, cation-anion balance in soil solution, presence of residues in the soil and relative air humidity, among others. To minimize the occurrence of this problem, weekly foliar applications of the fertilizer Ajifol ${ }^{\circledR}$ cálcio were performed in a concentration of $100 \mathrm{~mL} 100 \cdot \mathrm{L}^{-1}$ of water, and nutrient concentration was increased in the nutrient solution.

Mean mass of fruits showed a significant difference for the irrigation treatments and did not differ significantly between substrates. The lysimeter treatment produced a greater mean mass of fruits compared to evaporimeter, with a mean value of $94.75 \mathrm{~g}$.fruit ${ }^{-1}$. Charlo et al. (2009) found values of mean mass of fruits ranging from 170.00 to $257.25 \mathrm{~g}$ in different hybrids of yellow sweet bell pepper. The greater fruit mass obtained with the lysimeter irrigation system was probably related to the higher water levels, causing higher cell turgidity and increased fruit mass and volume (Lacerda
2007); moreover, due to the fact that irrigation solutions contain similar nutrient concentration levels, the highest water application rate was also associated to the higher amount of nutrients received by the plants in this treatment, thereby contributing for a greater fruit quality. No irrigation treatment effect was found with respect to mean fruit number per plant; however, substrates had a significant effect on this variable, with pinus bark resulting in more fruits per plant compared to coconut fiber (Table 3). According to Oliveira et al. (2013), the number of fruits produced might have a high variability in cultures depending on the growth cycle and the treatments employed, and it is directly related to plant yield.

Analyzing the effective use of water (EUW), which represents fresh fruit yield per water unit applied, the lysimeter irrigation treatment with coconut fiber substrate showed a higher value (Table 4). However, EUW values were generally lower than the values shown by Doorenbos and Kassam (1994) (1.5 to $3.0 \mathrm{~kg} \cdot \mathrm{m}^{-3}$ ) for this crop due to the low yield reached.

Table 5 shows the results for marketable bell pepper fruit length, cultivated under different irrigation systems and substrates. There was a significant interaction between the treatments and substrates assessed. It is noticeable that the longest length of marketable fruits was obtained with lysimeter in coconut fiber substrate; whereas there was no difference in the type of substrate used with evaporimeter.

Table 3. Mean values of total, marketable, non- marketable yield, production per plant, mean mass of bell pepper fruits, and fruit number per plant for the different types of irrigation treatments and substrates studied, under protected cultivation. Juazeiro, BA, 2014.

\begin{tabular}{|c|c|c|c|c|c|c|c|}
\hline & & $\begin{array}{l}\text { Yield Total } \\
\left(\mathbf{t} \cdot h \mathbf{a}^{-1}\right)\end{array}$ & $\begin{array}{c}\text { Yield } \\
\text { Marketable } \\
\left(t^{\prime} \cdot h \mathbf{a}^{-1}\right)\end{array}$ & $\begin{array}{c}\text { Yield non } \\
\text { Marketable } \\
\left(t \cdot h a^{-1}\right)\end{array}$ & $\begin{array}{l}\text { Production/ } \\
\text { plant (g) }\end{array}$ & $\begin{array}{l}\text { Mean Mass } \\
\text { fruits (g) }\end{array}$ & $\begin{array}{c}\text { Fruit } \\
\text { number/plant }\end{array}$ \\
\hline \multirow{3}{*}{ Management } & Lysimeter & $14.59 \mathrm{a}$ & $8.98 \mathrm{a}$ & $5.61 \mathrm{a}$ & $455.70 \mathrm{a}$ & $94.75 \mathrm{a}$ & $10.00 \mathrm{a}$ \\
\hline & Evaporimeter & $12.91 \mathrm{a}$ & $6.84 a$ & $6.07 a$ & $309.99 a$ & $73.98 \mathrm{~b}$ & $10.70 \mathrm{a}$ \\
\hline & CV\% & 19.43 & 47.86 & 24.84 & 46.01 & 15.01 & 31.97 \\
\hline \multirow{3}{*}{ Substrate } & Pinus bark & $13.76 \mathrm{a}$ & $8.20 \mathrm{a}$ & $5.56 a$ & $337.31 \mathrm{a}$ & $80.33 a$ & $10.95 a$ \\
\hline & Coconut fiber & $13.74 \mathrm{a}$ & $7.61 a$ & $6.13 a$ & $428.38 a$ & $88.40 \mathrm{a}$ & $9.75 b$ \\
\hline & CV\% & 23.67 & 43.55 & 31.22 & 41.90 & 20.83 & 33.05 \\
\hline
\end{tabular}

Means followed by the same lowercase letter in the columns do not differ statistically in Tukey's test $(p \leq 0.05)$.

Table 4. Marketable production, applied rate, and water use efficiency (WUE) in the different treatments applied, under protected cultivation. Juazeiro, BA, 2014.

\begin{tabular}{|c|c|c|c|}
\hline Management & Yield $\left(t \cdot h a^{-1}\right)$ & Plate applied (mm) & WUE (Kg·ha $\mathbf{~ m m}^{-1}$ ) \\
\hline Lysimeter - Pinus & 8.23 & 1773.5 & 4.6 \\
\hline Lysimeter-Coconut & 9.72 & 1618.5 & 6.0 \\
\hline Evaporimeter-Pinus & 8.18 & 1412.4 & 5.8 \\
\hline Evaporimeter-Coconut & 5.50 & 1412.4 & 3.9 \\
\hline
\end{tabular}


Cell growth depends on cell division and expansion, for which the presence of water is essential (Taiz and Zeiger 2009). Therefore, the higher water availability for plants in coconut fiber substrate in the lysimetry irrigation management enhanced cell growth, producing longer fruits.

For variables fruit diameter and length and diameter ratio, there was no interaction between the factors irrigation system and substrate (Table 6). The irrigation treatment showed a significant isolated effect on fruit diameter, while lysimeter management produced fruits with greater mean values. Length and diameter of fruits are important features, since they help determine fruit size and shape. When assessing different levels of water stress in the soil, Frizzone et al. (2001) observed that a lower water stress provided the highest values for these variables. On the other hand, Lima et al. (2012) observed that length and diameter of bell pepper fruits cv Konan R were not significantly influenced by irrigation treatments, showing maximum values of $14.68 \mathrm{~cm}$ and $6.83 \mathrm{~cm}$, respectively.

Only the substrate treatments revealed a significant effect on the fruit length and diameter ratio, with a higher value for coconut fiber. As mentioned by Charlo et al. (2009), this ratio is related to fruit shape, which is an important fruit characteristic, as the choice of pepper cultivar to be planted depends on market preferences.

Table 5. Length ( $\mathrm{mm}$ ) of marketable bell pepper fruits cultivated under different irrigation treatments and substrates, under protected cultivation. Juazeiro, BA, 2014.

\begin{tabular}{ccc} 
Irrigation Management & \multicolumn{2}{c}{ Substrates } \\
\cline { 2 - 3 } Regimes & Pinus Bark & Coconut Fiber \\
\hline Lysimeter & $81.38 \mathrm{aB}$ & $103.19 \mathrm{aA}$ \\
\hline Evaporimeter & $82.60 \mathrm{aA}$ & $82.16 \mathrm{bA}$ \\
\hline $\mathrm{CV} \%-\mathrm{a}=10.70$ & \multicolumn{2}{c}{$\mathrm{CV} \%-\mathrm{b}=10.74$} \\
\hline
\end{tabular}

Means followed by the same lowercase letter in the columns and uppercase letter in the rows do not differ statistically in Tukey's test $(p \leq 0.05)$.
Data on pulp thickness, soluble solids (SS), $\mathrm{pH}$, and titratable acidity (TA) of bell pepper fruits are shown in Table 7. A significant interaction between irrigation treatments and substrates was observed with respect to those variables.

A greater pulp thickness was observed in coconut fiber cultivation, regardless of the irrigation treatment used. On the other hand, pinus bark cultivation with the Piché evaporimeter produced fruits with lower pulp thickness. Frizzone et al. (2001) observed a significant difference in this variable under different water stress levels in the soil, with resulting mean pulp thickness of 2.5 to $5.6 \mathrm{~mm}$, with values that are close to the ones found in our study when they adopted the matric potential of $-32 \mathrm{kPa}$. Soares et al. (2013), evaluating the pulp thickness of the fruit in tomato plants irrigated with water rates ranging from 60 to $120 \%$ of

Table 7. Mean pulp thickness, soluble solids, $\mathrm{pH}$, and titratable acidity of bell pepper fruits cultivated under different irrigation treatments and substrates. Juazeiro, BA, 2014.

\begin{tabular}{|c|c|c|c|}
\hline & \multirow{2}{*}{$\begin{array}{c}\text { Irrigation } \\
\text { Management } \\
\text { Regimes }\end{array}$} & \multicolumn{2}{|c|}{ Substrates } \\
\hline & & Pinus Bark & Coconut Fiber \\
\hline \multirow{3}{*}{$\begin{array}{l}\text { Pulp Thickness } \\
(\mathrm{mm})\end{array}$} & Lysimeter & $4.82 \mathrm{aA}$ & $4.93 \mathrm{aA}$ \\
\hline & Evaporimeter & $3.83 \mathrm{bB}$ & $4.80 \mathrm{aA}$ \\
\hline & CV\%-a = 7.91 & \multicolumn{2}{|c|}{$C V \%-b=4.50$} \\
\hline \multirow{3}{*}{$\begin{array}{l}\text { Soluble Solids } \\
\quad\left({ }^{\circ} \text { Brix }\right)\end{array}$} & Lysimeter & $9.15 \mathrm{aA}$ & $6.87 \mathrm{bB}$ \\
\hline & Evaporimeter & $8.17 \mathrm{bA}$ & $8.66 \mathrm{aA}$ \\
\hline & CV\%-a = 9.77 & \multicolumn{2}{|c|}{ CV\%-b $=5.62$} \\
\hline \multirow{3}{*}{$\mathrm{pH}$} & Lysimeter & $5.18 \mathrm{bB}$ & $5.36 \mathrm{aA}$ \\
\hline & Evaporimeter & $5.44 \mathrm{aA}$ & $5.34 \mathrm{aA}$ \\
\hline & CV\%-a = 1.62 & \multicolumn{2}{|c|}{ CV\%-b = 1.68} \\
\hline \multirow{3}{*}{$\begin{array}{l}\text { Titratable Acidity } \\
\text { (g citric acid } \\
100 \mathrm{~g}^{-1} \text { pulp) }\end{array}$} & Lysimeter & $0.29 \mathrm{aA}$ & $0.23 \mathrm{bB}$ \\
\hline & Evaporimeter & $0.27 \mathrm{aA}$ & $0.29 \mathrm{aA}$ \\
\hline & $C V \%-a=12.00$ & \multicolumn{2}{|c|}{$C V \%-b=9.46$} \\
\hline
\end{tabular}

Means followed by the same lowercase letter in the columns and uppercase letter in the rows do not differ statistically in Tukey's test $(p \leq 0.05)$.

Table 6. Fruit diameter and length/diameter ratio of bell pepper cultivated under different irrigation treatments and substrates, under protected cultivation. Juazeiro, BA, 2014.

\begin{tabular}{cccc} 
& & Diameter of marketable fruit (mm) & Length/Diameter Ratio \\
\cline { 2 - 3 } Management & Lysimeter & $62.98 \mathrm{a}$ & $1.48 \mathrm{a}$ \\
\cline { 2 - 4 } & Evaporimeter & $54.21 \mathrm{~b}$ & $1.54 \mathrm{a}$ \\
\cline { 2 - 4 } & CV\% & 7.77 & 7.56 \\
\hline \multirow{2}{*}{ Substrate } & Pinus Bark & $59.72 \mathrm{a}$ & $1.35 \mathrm{~b}$ \\
& Coconut fiber & $57.46 \mathrm{a}$ & $1.67 \mathrm{a}$ \\
& $\mathrm{CV} \%$ & 10.75 & 6.62 \\
\hline
\end{tabular}

Means followed by the same lowercase letter in the columns do not differ statistically in Tukey's test $(p \leq 0.05)$. 
the actual evapotranspiration, observed that in the flowering and fruiting phase, the pulp thickness increased linearly with the increase in the amount of water provided.

Therefore, the higher water retention by coconut fiber substrate than pinus bark substrate might have contributed to a higher water availability for the plants, which in turn produced fruits with thicker pulps. Pulp thickness or mesocarp is the main constituent of the weight of the final product Fruits that have a thicker pulp are also more resistant to handling injury during transportation, resulting in longer post-harvest durability and higher yield, in addition to a higher market preference (Charlo et al. 2009).

Regarding soluble solids (SS), Table 7 shows that higher SS values were obtained when the lysimeter treatment was associated to pinus bark substrate. However, when considering management with evaporimeter, the coconut fiber substrate attained greater values. In general, SS values were considered high, reaching up to 9.15 in the pinus bark substrate and lysimeter treatment. Charlo et al. (2009) found soluble solid values that ranged from 5.85 to 7.42 , and no significant differences were observed between the hybrids assessed. Overall, sugar content is greater in fruits of plants grown under lower irrigation rates, due to the increased sugar concentration in fruit tissue, as observed by Fabeiro et al. (2002). Hence, although the lysimeter-based irrigation rate was higher, the lower amount of water available in the pinus bark substrate contributed to increase fruit SS contents in this treatment.

Regarding fruit $\mathrm{pH}$, higher values were obtained by the evaporimeter treatment and pinus bark-based cultivation. For lysimeter management, the highest values were found when using coconut fiber as substrate. Factor et al. (2008) did not find significant differences in $\mathrm{pH}$ when assessing different substrates and nutrient solutions, and found mean values that ranged from 4.95 to 5.04 .

Regarding titratable acidity, lysimeter management provided a greater value when conducted in pinus bark substrate, with a value of $0.29 \mathrm{~g}$ citric acid $100 \cdot \mathrm{g}^{-1}$ pulp. On the other hand, when conducted in coconut fiber, a higher acidity was recorded using evaporimeter management. Such values were greater than the ones found by Antoniali et al. (2007) ( $0.18 \mathrm{~g}$ of citric acid $100 \cdot \mathrm{g}^{-1}$ pulp). According to these authors, with the ripening of yellow sweet pepper fruits there is an increase in metabolic reactions, and consequently, increased concentration of organic acids.

\section{CONCLUSION}

The Piché evaporimeter-based irrigation management resulted in a lower water application per plant, with production (marketable and non-marketable) similar to lysimetry. This indicates more effective water use. However, the drainage lysimeter-based management resulted in higher quality characteristics, especially when associated to production on coconut fiber substrate.

Therefore, additional research involving different environmental conditions is required to identify the optimal pot size, varieties, and irrigation frequency to select the irrigation management system and the most suitable substrate for the crop, which result in a higher yield and greater fruit quality.

\section{ORCID IDs}

\author{
I. M. S. Santos \\ https://orcid.org/0000-0003-2451-7357 \\ P. P. Santos-Júnior \\ https://orcid.org/0000-0001-8851-445X \\ R. R. Silva \\ https://orcid.org/ 0000-0001-7239-0990 \\ G. M. Oliveira \\ https://orcid.org/0000-0002-7587-5800 \\ S. O. P. Queiroz \\ https://orcid.org/ 0000-0002-2083-2483
}

\section{REFERENCES}

Agrianual. (2012). Anuário da agricultura brasileira. São Paulo: FNP - Negócios e Consultoria.

Albuquerque, F.S., Silva, E. F. F., Albuquerque Filho, J. A. C. and Nunes, M. F. F. N. (2011). Crescimento e rendimento de pimentão fertirrigado sob diferentes lâminas de irrigação e doses de potássio. Revista Brasileira de Engenharia Agrícola e Ambiental, 15, 686-694. http://dx.doi.org/10.1590/ S141543662011000700006. 
Antoniali, S., Leal, P.A.M., Magalhães, A.M., Fuziki, R.T. and Sanchez, J. (2007). Physico-chemical characterization of 'Zarco HS' yellow bell pepper for different ripeness stages. Scientia Agricicola, 64, 19-22. http://dx.doi.org/10.1590/S0103-90162007000100003.

Ansorena Miner, J. (1994). Substratos, propiedades y caracterización, Bilbao: Mundi Prensa.

Blat, S. F. and Costa, C.P. (2007). A cultura do pimentão. Série Produtor Rural, 34. Piracicaba: ESALQ - Divisão de Biblioteca e Comunicação.

Carvalho, J.A., Rezende, F.C., Aquino, R.F., Freitas, W. A. and Oliveira, E. C. (2011). Análise produtiva e econômica do pimentão-vermelho irrigado com diferentes lâminas, cultivado em ambiente protegido. Revista Brasileira de Engenharia Agrícola e Ambiental, 15, 569-574. https://doi.org/10.1590/S1415-43662011000600005.

Ceagesp. (2014). Norma de Classificação do Pimentão para o Programa Brasileiro para a Melhoria dos Padrões Comerciais e Embalagens de Hortigranjeiros. [accessed on 2014 Nov. 8]. Available at: http://www.alimentares.com/pimentas/_file/norma_ pimentoes.pdf.

Charlo, H.C.O., Castoldi, R., Fernandes, C., Vargas, P.F. and Braz L.T. (2009). Cultivo de híbridos de pimentão amarelo em fibra da casca de coco. Horticultura Brasileira, 27, 155-159. http://dx.doi. org/10.1590/S0102-05362009000200006.

DeBoodt, M. and Verdonck, O. (1972). The physical properties of the substrates in horticulture. Acta Horticulturae, Wageningen, 26, 37-44.

Doorenbos, J. and Kassam, A. H. (1994). Efeito da água no rendimento das culturas. Campina Grande: UFPB. FAO, Estudos de irrigação e drenagem, 33.

Doorenbos, J. and Kassam, A.H. (2000). Efeito da água no rendimento das culturas. Campina Grande: Tradução Gheyi H.R. e outros, UFPB FAO.

Fabeiro, C., Olalla, F.M.S. and Juan, J.A. (2002). Production of muskmelon (Cucumis melo L.) under controlled deficit irrigation in a semi-arid climate. Agricultural water management. Fresno, 54, 93-105. http://dx.doi.org/10.1016/S03783774(01)00151-2.

Factor, T.L., Araujo, J.A.C. and Vilella Junior, L.V.E.. 2008. Produção de pimentão em substratos e fertirrigação com efluente de biodigestor. Revista Brasileira de Engenharia Agrícola e Ambiental, Campina Grande, 12, 143-149. http://dx.doi.org/ 10.1590/S1415-43662008000200006.
Fain, G.B., Gilliam, C.H., Sibley, J.L. and Boyer, C.R. (2008). Wholetree substrates derived from three species of pine in production of annual vinca. HortTechnology, 18, 13-17.

Fermino, M.H. and Kämpf, A.N. (2012). Densidade de substratos dependendo dos métodos de análise e níveis de umidade. Horticultura Brasileira, 30, 75-79.

Fontes, P.C.R. (2003). Podridão apical do tomate, queima dos bordos das folhas de alface e depressão amarga dos frutos em maçã: deficiência de Ca. Horticultura Brasileira, Brasília, 21, 145. http://dx.doi.org/10.1590/S0102-05362003000200003.

Furlani, R.A., Botrel, T.A. and Paz, V.P.S. (1998). Consumo de água pela cultura do crisântemo envasado sob condições de casa de vegetação. Revista Brasileira de Engenharia Agrícola e Ambiental, 2, 52-55.

Frizzone, J.A., Gonçalves, A.C.A. and Rezende, R. (2001). Produtividade do pimentão amarelo, Capsicum annuum L., cultivado em ambiente protegido, em função do potencial mátrico de água no solo. Acta Scientiarum, 23, 1111-1116. http://dx.doi.org/10.4025/ actasciagron.v23i0.2567.

Goto, R. and Rossi, F. (1997). Cultivo de pimentão em estufa Manual. Viçosa: CPT.

Heldwein, A. B., Dalmago, G. A., Streck, L., Tazzo, I. F. and Trentin, G. (2001). Utilização do evaporímetro de Piche exposto á radiação solar para estimar a evapotranspiração máxima do pimentão em estufa plástica. Revista Brasileira de Agrometeorologia, 9, 213-217. Instituto Adolfo Lutz. (2004). Normas Analíticas do Instituto Adolfo Lutz: Métodos Químicos e Físicos Para Análise de Alimentos. 3 ed. São Paulo: IAL.

Lacerda, C. F. (2007). Déficit hídrico e crescimento vegetal: Mecanismos fisiológicos, processos e fenologia. In C.F. Lacerda (Ed.), Relações solo-água-planta em ambientes naturais e agrícolas do nordeste brasileiro. Recife: Universidade Federal de Pernambuco. v. 1 , cap. 8, p. 70-78.

Lima, E.M.C., Matiolli, W., Thebaldi, M.S., Rezende, F.C. and Faria, M.A. (2012). Produção de pimentão cultivado em ambiente protegido e submetido a diferentes lâminas de irrigação. Revista Agrotecnologia, 3, 40-56. http://dx.doi.org/10.7127/rbai.v6n300086.

Lima, P. A., Montenegro, A. A. A., Lira Junior, M. A., Santos, F. X. and Pedrosa, E. M. R. (2006). Efeito do manejo da irrigação com água moderadamente salina na produção de pimentão. Revista Brasileira de Ciências Agrárias, 1, 73-80. 
Lorentz, L. H., Lúcio, A. D., Heldwein, A. B., Souza, M. F. and Mello, R. M. (2002). Estimativa da amostragem para pimentão em estufa plástica. Horticultura Brasileira, 20, n.2. Suplemento 2. CD Rom.

Lúcio A.D., Couto M.R.M., Lopes S.J. and Storck L. (2011). Transformação boX-coX em eXperimentos com pimentão em ambiente protegido. Horticultura Brasileira, 29, 38-42.

MAPA-Ministério da Agricultura, Pecuária e Abastecimento. Instrução Normativa n 17, de 21 de maio de 2007. Aprova os Métodos Analíticos Oficiais para Análise de Substratos e Condicionadores de Solos, na forma do Anexo à presente Instrução Normativa. [accessed on 2014 Nov. 1]. Available at http:// extranet.agricultura.gov.br/sislegisconsulta/consultarLegislacao. do?operacao=visualizar\&id=17762.

Oliveira, F. A., Duarte, S. N., Medeiros, J. F., Dias, N. S., Silva, R. C. P. and Lima, C. J. G. S. (2013). Manejos da fertirrigação e doses de $\mathrm{N}$ e K no cultivo de pimentão em ambiente protegido. Revista Brasileira de Engenharia Agrícola e Ambiental, 17, 1152-1159. http:// dx.doi.org/10.1590/S1415-43662013001100004.

Pereira, R. B., Lucas, G. C. and Pinheiro, J. B. (2011). Oídio em pimentão. Nosso Alho, 12, 43-48.

Pivetta, C. R., Heldwein, A. B., Maldaner, I. C., Radons, S.R., Tazzo, I. F. and Lucas, D. D. P. (2011). Evapotranspiração máxima do tomateiro cultivado em estufa plástica em função de variáveis fenométricas e meteorológicas. Bragantia, 70, 707-714. http://dx.doi.org/10.1590/ S0006-87052011000300029.

Ribeiro, C.S.C. and Cruz, D. M. R. (2002). Tendências de Mercado. Revista Cultivar Hortaliças e Frutas, n. 14. [accessed on 2017 May 27]. Available at: http://www.grupocultivar.com.br/site/content/ artigos/artigos.php?id=406.
Silva, F.A. S. E. and Azevedo, C. A. V. (2002). Versão do programa computacional Assistat para o sistema operacional Windows. Revista Brasileira de Produtos Agroindustriais, 4, 71-78.

Soares, L.A.A., Brito, M.E.B., Silva, E.C.B., Sá, F.V.S. and Araújo, T.T. (2013). Componentes de produção do tomateiro sob lâminas de irrigação nas fases fenológicas. Revista Verde de Agroecologia e Desenvolvimento Sustentável, 8, 84-90.

Sonneveld, C. and Van Elderen, C.W. (1994). Chemical analysis of peaty growing media by means of water extraction. Communications in Soil Science and Plant Analysis, New York, 5, 183-202.

Sorace, M., Faria, R. T., Fonseca, I. C. B., Yamamoto, L. Y. and Sorace, A. A.F. (2009). Substratos alternativos ao xaxim no cultivo do híbrido Cattleya intermedia X Hadrolaelia purpurata (Orchidaceae). Semina: Ciências Agrárias, 30, 771-778. http:// dx.doi.org/10.5433/1679-0359.2009v30n4p771.

Taiz, L. and Zeiger, E. (2009). Fisiologia vegetal. 4.ed. Porto Alegre: Artmed.

TEIXEIRA, A. H. C. (2010). Informações agrometeorológicas do polo Petrolina, PE/Juazeiro, BA - 1963 a 2009. Petrolina: Embrapa Semiárido, Documentos, n.233. 21p. [accessed on 2014 Nov. 24]. Available at: https://www.infoteca.cnptia.embrapa.br/bitstream/ doc/883657/1/SDC233.pdf

Tivelli, S. W. (1998). A cultura do pimentão. In R.Goto and S.W. Tivelli (Org.), Produção de Hortaliças em Ambiente Protegido: Condições subtropicais. São Paulo: Fundação Editora da UNESP. Trani, P.E. and Carrijo, O.A. (2004). Fertirrigação em hortaliças. Campinas: Instituto Agronômico. Boletim Técnico IAC, 196.

Zorzeto, T. Q., Dechen, S. C. F., Abreu, M. F. and Fernandes Júnior, F. (2014). Caracterização física de substratos para plantas. Bragantia, 73, 300-311. http://dx.doi.org/10.1590/1678-4499.0086. 